\title{
Food Habits of the Red Fox in Greece
}

\author{
Nicolaos K. PAPAGEORGIOU, Athanasios SEPOUGARIS, \\ Olga G. CHRISTOPOULOU, Christos G. VLACHOS \& \\ John S. PETAMIDIS
}

\begin{abstract}
Papageorgiou N. K., Sfougaris A. I., Christopoulou O. G., Vlachos Ch. G. \& Petamidis J. S., 1988: Food habits of the red fox in Greece. Acta theriol., 33, $23: 313-324$ [With 3 Tables \& 1 Fig.]

The stomach contents of 190 red foxes Vulpes vulpes (Linnaeus, 1758), collected throughout Greece during 1982-85, were examined for prey remains. Of these, 165 stomachs contained measurable quantities of food. The fox had a wide dietary range, consisting of approximately 70 prey species. The main food groups were of vertebrate origin, supplemented by invertebrates, grasses and fruits. The main food items were small rodents, domestic mammals, apples and domestic chickens. Game mammals and birds did not play a significant role as prey in the fox's dietary needs. The observed regional and seasonal variations in the fox's prey reveal the opportunistic feeding behavior of the fox, utilizing mainly foods which are more abundant and easily obtainable.

[Department of Forestry and Natural Environment, University of Thessaloniki, (Box 241) 540 06, Thessaloniki (N.K.P., A.I.S., O.G.C., and C.G.V.), Ministry of Agriculture, Greek Forest Service, Hipocratous 3-5, Athens (J.S.P.) Greece].
\end{abstract}

\section{INTRODUCTION}

Food habits of the red fox Vulpes vulpes (Linnaeus, 1758) have been reported by a number of authors (Murie, 1936; Southern \& Watson, 1941; Scott, 1943; Englund, 1965; Richards, 1977). The main prey of the red fox includes small rodents and rabbits (Richards \& Hine, 1953; Karpuleon, 1958; Korschgen, 1959; Englund, 1965; 1969; Fairley, 1970; Coman, 1973, and Richards, 1977). Other mammals and birds are not frequently consumed and larger wild and domestic animals are often taken as carrion (Baranovskaya \& Kolosov, 1935; Cook \& Hamilton, 1944; Vesey-Fitzgerald, 1965; Burrows, 1968). Fruits, insects and earthworms are also reported as part of the fox's diet (Scott \& Klimstra, 1955; Korschgen, 1959; Coman, 1973; Rayn \& Croft, 1974). Previous studies on the food habits of the red fox in Europe, Australia, and North America have shown that, in general, red foxes are opportunists and utilize foods which are most abundant and easily obtainable at a particular time (Scott, 1943; Watson, 1955; McIntosh, 1963; Coman, 1973; Richards, 1977). 
The red fox is one of the most abundant and widely distributed wild members of the Canidae family in Greece. However, information on their food habits in Greece is limited (Papageorgiou et al., 1981). Furthermore, a popular belief is that fox predation has contributed to the decline of many species of game mammals and birds. The latter was the main reason for the initiation of a nationwide bounty program which started in the late 40's in an effort to reduce fox numbers. As a result of the bounty system and the high price of the fox pelt, during the last decade (1975-1984) 558,099 foxes were killed in Greece and the state paid for the predator control program approximately 200 million drachmas.

The objectives of the present study, which was conducted from March 1982 to January 1985 , were to obtain information on the diet of the red fox to ascertain seasonal and regional variations in prey and to determine the extent of red fox predation upon game animals.

\section{MATERIAL AND METHODS}

Most of the stomachs were supplied voluntarily by hunters and trappers. Others were obtained by local game wardens. A variety of methods were employed to obtain the specimens including organized drives, trapping, fumigation of dens, and night shooting with the aid of spotlights.

The stomach of each fox was stored in a $10 \%$ formalin solution. Date, time, area of capture, and size of the animal were also recorded. The contents of each stomach were first washed with hot water through a 12 mesh screen sieve to remove grease and later with cold tap water under heavy pressure. Identification of the food items was made with identified reference materials, pictorial references, skin and skeleton materials of vertebrates, and whole specimens of invertebrates.

Inspection of guard hair structure was used to identify mammalian remains (Mathiak, 1938; Mayer, 1952; Stains, 1958). Bird remains were difficult to identify except in those cases where a substantial part of their plumage was present in the stomach. Feathers were identified to order by examining the morphology of the nodes of their barbules (Day, 1966). Unkown items found in the first samples were numbered until better and identifable specimens were found.

The data were treated in three ways. First, percentage occurrences were calculated from the ratio between the number of times a particular food item was found in the stomachs to the total number of stomachs examined. Second, percentage volumes were calculated from the ratio between the volumes of specific food items and the total volume of food found in the stomachs. Third, percentage weights were calculated from the ratio between the dry weights of specific food items and the total dry weight of food found in the stomachs. A combination of these methods seemed to be the most useful way of presenting the data. None of the methods alone is entirely satisfactory since all have shortcomings (Swanson, 1940; Englund, 1965). 


\section{RESULTS}

\subsection{General Feeding Trends}

A total of 190 stomachs were collected troughout Greece over a 3-year period of study. 100 stomachs were collected from Northern Greece while 45 and 45 stomachs were collected from Central and Southern Greece, respectively. Seasonally the sample was greater in winter $(43.2 \%)$ than that obtained in spring $(21 \%)$, autumn $(20 \%)$, and summer $(15.8 \%)$.

Of the 190 red fox stomachs examined, 165 (86.8\%) contained measurable amounts of food and $25(13.2 \%)$ were completely empty or contained only traces of food. The percentage of empty stomachs was almost constant in the samples obtained in winter $(15.8 \%)$, spring $(15 \%)$ and autumn $(13.1 \%)$ but was relatively lower $(3.3 \%)$ in summer.

The general food categories found in the fox stomachs are shown in Table 1. The data show that the fox's staple diet was of vertebrate origin $(84.6 \%$ of total volume and $91.1 \%$ of the total weight of the ingested food) and was supplemented by invertebrates, fruits and grasses.

Table 1

Seasonal variation of the major food groups in the 165 fox stomachs. Occ. $\%$ or thentage of occurrence, $\mathrm{V} \%$ o centage of volume, $\mathrm{W}^{\%} \%$ - percentage of weight, ${ }^{*}-$ traces.

\begin{tabular}{crrrrr}
\hline Food category & $\begin{array}{c}\text { Spring } \\
(\mathrm{n}=34)\end{array}$ & $\begin{array}{c}\text { Summer } \\
(\mathrm{n}=29)\end{array}$ & $\begin{array}{c}\text { Autumn } \\
(\mathrm{n}=33)\end{array}$ & $\begin{array}{c}\text { Winter } \\
(\mathrm{n}=69)\end{array}$ & $\begin{array}{c}\text { Whole } \\
\text { year }\end{array}$ \\
\hline Mammals & & & & & \\
Occ. \% & 55.8 & 72.4 & 78.7 & 81.1 & 73.9 \\
V \% & 13.5 & 9.8 & 11.8 & 23.9 & 58.9 \\
W \% & 15.4 & 8.4 & 10.9 & 27.4 & 63.3 \\
Birds & & & & & \\
Occ. \% & 47.0 & 44.8 & 33.3 & 46.3 & 43.6 \\
V \% & 5.9 & 2.5 & 1.5 & 13.5 & 23.6 \\
W \% & 7.9 & 2.9 & 2.3 & 14.3 & 25.4 \\
Cold-blooded & & & & & \\
Vertebrates & & & & & \\
Occ. \% & 23.5 & 31.0 & 6.0 & - & 11.5 \\
V \% & 0.8 & 0.8 & 0.5 & - & 2.1 \\
W \% & 0.7 & 1.1 & 0.6 & - & 2.4 \\
Invertebrates & & & & & \\
Occ. \% & 44.1 & 75.8 & 30.3 & 14.4 & 49.7 \\
V \% & 0.6 & 1.9 & 0.6 & 0.2 & 3.6 \\
W \% & 0.7 & 1.1 & 0.6 & & 2.3 \\
Plant material & & & & & \\
Occ. \% & 47.0 & 72.4 & 78.7 & 57.9 & 62.4 \\
V \% & 1.2 & 4.3 & 2.3 & 4.5 & 11.8 \\
W \% & 0.6 & 2.3 & 0.9 & 1.9 & 6.6 \\
\hline
\end{tabular}


Concerning the frequency of occurrence, mammals were the major food source $(73.9 \%)$ followed by vegetation material $(62.4 \%)$, invertebrates $(49.7 \%)$, birds $(43.6 \%)$ and cold-blooded vertebrates $(11.5 \%)$. When volume and weight are considered, the bulk of the stomach contents consisted of mammals and birds while the other foods were of secondary importance.

The data showed differences among the three physiographic regions of Greece in relation to major food groups. However, statistical analysis showed that these were not significant at a probability level of 0.05 .

\subsection{Specific Food Items}

Mammals. Of the 70 species which were found to constitute the fox's diet, 19 species were mammals (Table 2).

Small rodents constituted the staple diet of the fox since they were found in $69(41.8 \%)$ stomachs, comprising $23.1 \%$ of the diet by volume and $18.9 \%$ by weight. The fox's preference for small rodents was evident by the fact that in 15 stomachs, where the counting of individual animals was possible, 4 to 9 small rodents were found. Sheep, together with pigs also comprised an important part of the fox's diet.

Table 2

Mammals found in the 165 fox stomachs; * - traces.

\begin{tabular}{|c|c|c|c|c|}
\hline \multirow[b]{2}{*}{ Food item } & \multicolumn{2}{|l|}{ Occurrence } & \multirow{2}{*}{$\begin{array}{c}\text { Volume } \\
\%\end{array}$} & \multirow{2}{*}{$\begin{array}{c}\text { Dry weight } \\
\%\end{array}$} \\
\hline & $\begin{array}{l}\text { No. of stomachs } \\
\text { in which given } \\
\text { item was found }\end{array}$ & $\%$ & & \\
\hline Small rodents & 69 & 41.8 & 23.1 & 18.9 \\
\hline Ovis aries & 20 & 12.1 & 10.4 & 13.3 \\
\hline Sus scrofa dom. & 13 & 7.9 & 6.4 & 8.1 \\
\hline Bos taurus & 9 & 5.4 & 4.6 & 5.8 \\
\hline Capra hircus & 7 & 4.2 & 2.0 & 2.1 \\
\hline Canis familiaris & 5 & 3.0 & 2.9 & 2.8 \\
\hline Equus asinus & 4 & 2.4 & 0.1 & 0.4 \\
\hline Felis catus & 4 & 2.4 & 2.8 & 2.6 \\
\hline Martes foina & 3 & 1.8 & 0.1 & 1.9 \\
\hline Lepus europaeus & 3 & 1.8 & 2.1 & 1.7 \\
\hline Equus caballus & 2 & 1.2 & 0.2 & 0.2 \\
\hline Meles meles & 2 & 1.2 & 0.2 & 0.2 \\
\hline Vulpes vulpes & 2 & 1.2 & 0.1 & 0.6 \\
\hline Mustela nivalis & 2 & 1.2 & 0.6 & 0.4 \\
\hline Mustela putorius & 1 & 0.6 & 0.2 & 0.1 \\
\hline Sriurus vulgaris & 1 & 0.6 & 1.6 & 3.4 \\
\hline Felis silvestris & 1 & 0.6 & 1.5 & 0.8 \\
\hline Cervus elaphus & 1 & 0.6 & $*$ & $*$ \\
\hline Capreolus capreolus & 1 & 0.6 & * & * \\
\hline
\end{tabular}


Remains of large domestic animals (cattle, horse, donkey etc.) were found to be present in a considerable number of specimens. Hares, even though they were available in the three regions, were found only in three stomachs.

Plant material. Plants consisted of grasses and fruits. A total 19 different species of fruits were found in the fox's diet (Table 3). Although grass was found in $27.2 \%$ of the stomachs examined, it was present only in minute quantities comprising only $1.8 \%$ of the total fox's diet by volume. Among the various fruits, apples and almond-leaved pears were found to constitute the most important fruits in the fox's diet. Seasonal variation in the percentage of occurence showed that fruits were consumed more frequently in summer and autumn than at any other time of the year.

Birds. Domestic chickens proved to be the priaciple avian food identified in the stomach contents. Feathers of domestic chickens were found in $16.3 \%$ of the examined stomachs and constituted $13.5 \%$ of the fox's diet by volume (Table 3). Passerine birds appeared in $16.9 \%$ of the

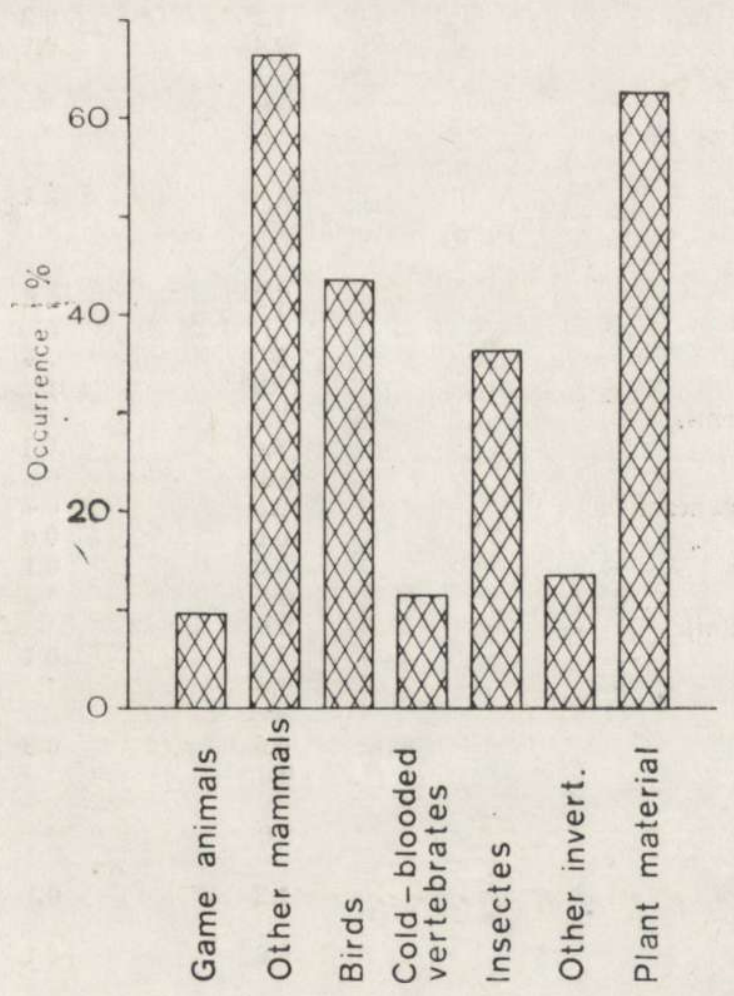

Fig. 1. The percentage of occurrence of the major food groups found in the fox stomachs. 
Table 3

Food items found in 165 fox stomachs in Greece; * - traces.

\begin{tabular}{|c|c|c|c|}
\hline Food item & $\%$ Occ. & $\% \mathrm{~V}$ & $\% \mathrm{~W}$ \\
\hline \multicolumn{4}{|c|}{ Mammals } \\
\hline Small rodents & 41.8 & 23.1 & 18.9 \\
\hline Sciurus vulgaris & 0.6 & 1.6 & 3.4 \\
\hline \multicolumn{4}{|l|}{ Canidae } \\
\hline Canis familiaris & 3.0 & 2.9 & 2.8 \\
\hline Vulpes vulpes & 1.2 & 0.1 & 0.6 \\
\hline \multicolumn{4}{|l|}{ Mustelidae } \\
\hline Meles meles & 1.2 & 0.2 & 0.2 \\
\hline Martes foina & 1.8 & 0.1 & 1.9 \\
\hline Mustela nivalis & 1.2 & 0.6 & 0.4 \\
\hline Mustela putorius & 0.6 & 0.2 & 0.1 \\
\hline \multicolumn{4}{|l|}{ Felidae } \\
\hline Felis catus & 2.4 & 2.8 & 2.6 \\
\hline Felis silvestris & 0.6 & 1.5 & 0.8 \\
\hline \multicolumn{4}{|l|}{ Bovidae } \\
\hline Bos taurus & 5.4 & 4.6 & 5.8 \\
\hline Ovis aries & 12.1 & 10.4 & 13.3 \\
\hline Capra hircus & 4.2 & 2.0 & 2.1 \\
\hline \multicolumn{4}{|l|}{ Suidae } \\
\hline Sus scrofa dom. & 7.9 & 6.4 & 8.1 \\
\hline \multicolumn{4}{|l|}{ Equidae } \\
\hline $\begin{array}{l}\text { Equus caballus } \\
\text { Equus asinus }\end{array}$ & $\begin{array}{l}1.2 \\
2.4\end{array}$ & $\begin{array}{l}0.2 \\
0.1\end{array}$ & $\begin{array}{l}0.2 \\
0.4\end{array}$ \\
\hline \multicolumn{4}{|l|}{ Cervidae } \\
\hline Cervus elaphus & 0.6 & $*$ & $*$ \\
\hline Capreolus capreolus & 0.6 & * & * \\
\hline \multicolumn{4}{|l|}{ Leporidae } \\
\hline Lepus europaeus & 1.8 & 2.1 & 1.7 \\
\hline & ial & & \\
\hline \multicolumn{4}{|l|}{ Vitaceae } \\
\hline $\begin{array}{l}\text { Vitis vinifera } \\
\text { Rosaceae }\end{array}$ & 7.2 & 1.6 & 0.5 \\
\hline \multicolumn{4}{|l|}{ Rosaceae } \\
\hline $\begin{array}{l}\text { Pyrus communis } \\
\text { Pyrus malus }\end{array}$ & $\begin{array}{r}9.0 \\
11.5\end{array}$ & $\begin{array}{l}1.4 \\
1.7\end{array}$ & 0.6 \\
\hline $\begin{array}{l}\text { Pyrus malus } \\
\text { Pyrus amygdaliformis }\end{array}$ & 7.8 & 1.7 & 0.9 \\
\hline $\begin{array}{l}\text { Pyrus amygdaliformis } \\
\text { Pyrus malus }\end{array}$ & 3.0 & 0.1 & $*$ \\
\hline Pyrus pyraster & 0.6 & 0.3 & 0.5 \\
\hline Prunus pseudoarmeniaca & 0.6 & 0.4 & 0.2 \\
\hline Prunus persica & 0.6 & 0.6 & 0.1 \\
\hline Prunus armeniaca & 0.6 & 0.1 & 0.1 \\
\hline Prunus sp. & 0.6 & $*$ & * \\
\hline Amygdalis communis & 0.6 & $*$ & $*$ \\
\hline Rosa canina & 1.2 & 0.1 & 0.1 \\
\hline Crataegus sp. & 0.6 & $*$ & ${ }^{*}$ \\
\hline \multicolumn{4}{|l|}{ Moraceae } \\
\hline Morus alba & 0.6 & 0.8 & 0.2 \\
\hline Ficus carica & 0.6 & $*$ & $*$ \\
\hline \multicolumn{4}{|l|}{ Juglandaceae } \\
\hline Juglans regia & 3.0 & $*$ & $*$ \\
\hline \multicolumn{4}{|l|}{ Betulaceae } \\
\hline $\begin{array}{l}\text { Corylus sp. } \\
\text { Cornaceae }\end{array}$ & 1.2 & 0.1 & 0.1 \\
\hline $\begin{array}{l}\text { Cornaceae } \\
\text { Cornus sp. }\end{array}$ & 0.6 & 0.1 & 0.1 \\
\hline \multicolumn{4}{|l|}{ Cistaceae } \\
\hline Cistus sp. & 0.6 & * & * \\
\hline
\end{tabular}

continued on p. 319 
Table 3. concluded.

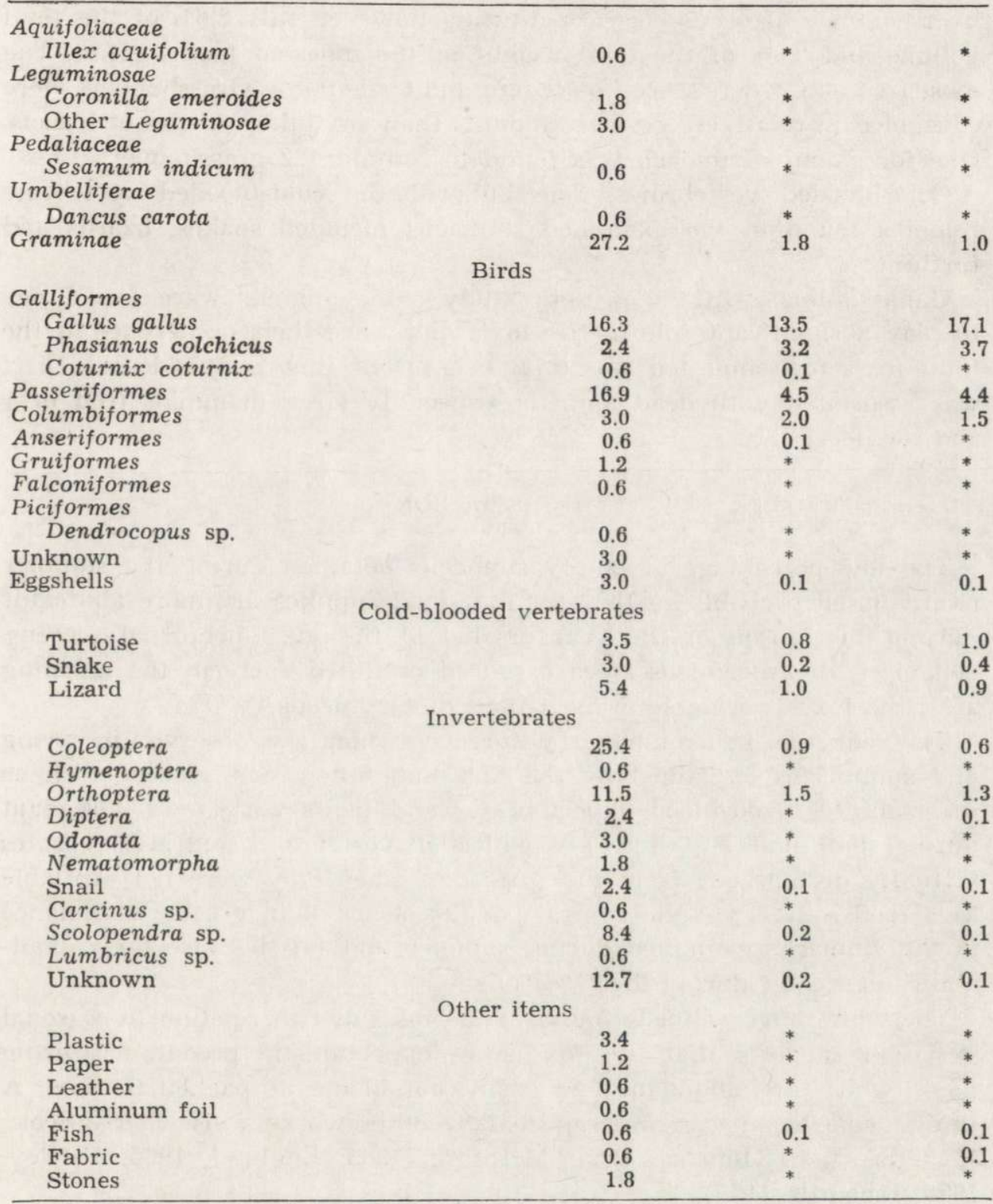

stomachs examined and constituted $4.5 \%$ of the volume of the food consumed. Game birds were found to be present in a much smaller proportion of the examined stomachs than expected. Pheasant and quail remains appeared in 4 and 1 stomachs, respectively. There were 5 stomachs found to contain unidentified fragments of eggshells.

Invertebrates. Insects were found to constitute the major portion of 
the invertebrate diet of the fox. Insects occurred in $52.6 \%$ of the diet by frequency of occurrence constituting however only $2.6 \%$ of the total volume and $2.0 \%$ of the total weight of the ingested food by fox. The most frequent orders were Coleoptera and Orthoptera. Grasshoppers were consumed in relatively greater amounts than any other species of insects. One for example stomach was found to contain 122 grasshoppers.

Cold-blooded vertebrates. The bulk of the cold-blooded vertebrate remains found in the examined stomachs included snakes, lizards and turtles.

Game animals. In the present study game animals were found not to play a significant role in the fox's diet since their occurrence in the total fox's food ingested was $9.7 \%$ (Fig. 1) of this, a considerable part was associated with dead animals, especially large mammals (red deer and roe deer).

\section{DISCUSSION}

The low percentage of empty stomachs obtained during the summer is attributed probably to the fact that food supplies are more abundant during this season of the year or due to the fox's nocturnal feeding behavior. The specimens were captured or killed early in the morning after the foxes were able to meet their dietary needs.

The reduction in mammalian occurrence which was observed in spring and summer is explained by the fact that other food sources such as invertebrates, cold-blooded vertebrates and fruits were more abundant during that time. By winter, cold-blooded vertebrates and invertebrates virtually disappeared from the fox's diet since they were not available as a food source. On the contrary fruits occurred in greater abundance in the stomachs examined during summer and fall because their availability is greater during these seasons.

The wide range of foods found in the fox's diet in relation to seasonal variation suggests that the fox is an opportunistic predator utilizing foods which are abundant and easily obtainable at particular time. A similar conclusion was also reported by other workers elsewhere (Scott, 1943; Scott \& Klimstra, 1955; McIntosh, 1963; Englund, 1965; Fairley, 1970; Richards, 1977).

The data showed that the fox is primarily a carnivore preying mainly on small mammals or feeding on the carcasses of large ones. The most important food of the fox is small rodents, making therefore the fox a valuable animal in biological control of rodent populations. The importance of small rodents in the fox's diet has also been found in many other extensive studies conducted in Scandinavia (Lund, 1959; Englund, 1965), Australia (McIntosh, 1963; Coman, 1973; Ryan \& Croft, 1974), 
North America (Scott, 1943; Hamilton, 1935; Errington, 1937; Karpuleon, 1958), England (Watson, 1955; Fairley, 1970; Richards, 1977) and many other parts of the world.

Rodent consumption by foxes was higher during summer, coinciding with their main breeding season. In addition, the harvest of agricultural crops during this time of the year eliminates the vegetation cover. This results in a high rodent concentration in nearby areas with natural vegetation, therefore making their capture by foxes easier.

Large domestic animals were found to comprise a considerable part of the fox's diet. These mammalian remains were associated with dead animals discarded by farmers or killed by other larger predators. Young animals (lambs, goats and piglets) which can be killed by the fox may be exceptions. The fox's preference towards dead domestic animals was higher in winter when other foods were scare or were not easily captured. Baranovskaya \& Kolosov (1935) indicated that carrion feeding was of fundamental importance for Russian foxes in winter. This finding agrees also with many other researchers who have pointed out the importance of dead domestic animals as a winter food source for the fox (Scott, 1943; McIntosh, 1963; Lockie, 1959; Vesey-Fitzgerald, 1965; Dennis, 1965; Burrows, 1968; Alexander et al., 1955; Coman, 1973; Richards, 1977).

Insectivora, despite their abundance, constituted only a small part of the fox's diet. Experimental trials have shown that shrews are rejected by foxes if other food is available (Lund, 1959). It seems probable that the lack of palatability is associated with the secretion of the flank gland. Scott (1943) also reported that moles are also unpalatable, like shrews.

The presence, in two stomachs of the remains of a fox's foot reveals that dead foxes were also eaten by the fox. This finding agrees with that reported by Englund (1965). The presence, in a few specimens, of traces of fox fur is probably explained by fur ingested while the coat was being cleaned. Fox is over-rated as a predator on hares. In this study they constituted only a small part of the fox's diet. This is probably associated with the high speed of this animal making it very difficult to be captured by the fox or the neglectance of the fox to hunt such prey when other species, more easily obtainable, are available.

Grass was the most common plant ingested in minute quantities. Lund (1962) considers it possible that foxes satisfy part of their vitamin C requirements by eating grass. Richards (1977) however suggests that this seems unlikely in view of the fox's ability to synthesize this vitamin.

Fruits were found in the examined stomachs in all seasons and mainly in summer and autumn when they most abundant. Fruits provide an easily available source of carbohydrates and their frequent presence 
in the fox's diet has been noted also by Scott (1943), Lever (1959), Burrows (1969) and Richards (1977).

Predation on game and domestic birds is the subject of much discussion (Middleton, 1957; Karpuleon, 1958; Schofield, 1960; Burrows, 1968; Fairley, 1970). In the present study, fox predation on game birds could be described as slight even though thousands of artificially reared pheasants and partridges were released for shooting purposes by the Forest Service.

In a few cases where remains of pheasants and quails were found it was not easy to prove if they were taken as live prey or as carrion. It seems likely that fox predation on game birds and especially on ground nesting ones can be heavy only in those situations where the birds are abundant and more easily obtainable than other prey. As Richards (1977) points out, the availability of birds wounded or killed by hunter and not recovered may also influence their general importance in the fox's diet.

The economic consequence of fox predation on domestic birds and especially chicken is difficult to assess. In our study it is evident that the chicken is a frequent food of foxes. It is generally agreed that a part of the domestic chicken fed upon by foxes in carrion (Errington, 1935; Hamilton, 1935). The regional variation of the chicken in the fox's diet found in the present study suggests that fox's predation on chickens is probably associated with the way of sheltering them during the night.

Fragments od eggshells were found in a few stomachs but the species of origin could not be determined. In two cases however it is sure that they belonged to chickens since than were found in specimens taken during the winter. Baranovskaya \& Kolosov (1935) in their study on food habits in Russia also suggested that foxes usually break eggs and lap their contents.

Invertebrates, chiefly insects, are a common summer food of foxes but account for only a small part of the total food volume consumed by foxes, except the grasshoppers. Some stomachs were almost entirely filled with grasshoppers, making this insect significant source of easily obtained food for the fox.

Reptiles and amphibians, reasonably common over much of the area sampled, were scarce in the fox's diet. Scott and Klimstra (1955) made a similar observation on foxes in an area of Iowa. McIntosh (1963) also mentions that snakes offered to captive foxes were never eaten.

From this study it can be concluded that the fox is an opportunistic predator and scavenger. It eats a wide range of food, the predominant items being of vertebrate origin, supplemented by invertebrates and fruits. Dietary changes are mainly connected with the relative availability of prey species. The major food item which forms the bulk of the fox's diet was prey which was easy to capture. 


\section{REFERENCES}

1. Alexander G., McCance I. \& Watson R. H., 1955: Some observations on losses among merino lambs. Aust. Vet. J., 31: 85-99.

2. Baranovskaya T. N. \& Kolosov A. M., 1935: Food habits of the fox (Vulpes vulpes L.). Zool. Zh., 14: 523-550.

3. Burrows B., 1968: Wild fox. David and Charles, London.

4. Coman B. J., 1973: The diet of red foxes (Vulpes vulpes) in Victoria. Aust. J. Zool., 21: 391-401.

5. Cook D. B. \& Hamilton W. J., 1944: The ecological relationship of red fox food in eastern New York. Ecology, 23: 91-104.

6. Day M. G., 1966: Identification of hair and feather remains in the gut and faeces of stoats and weasels. J. Zool., 148: 201-207.

7. Dennis S. M., 1965: More light on dead lambs. Third and final report of a survey of lamb mortalities in W. A. J. Agric. West. Aust., 6: 686-689.

8. Englund J., 1965: Studies on food ecology of the red fox in Sweden. Viltrevy, 3: $378-473$.

9. Englund J., 1969: The diet of fox cubs (Vulpes vulpes) in Sweden. Viltrevy, $6(1): 1-39$

10. Errington P. L., 1935: Food habits of mid-West foxes'. J. Mammal., 16: $192-200$.

11. Errington P. L., 1937: Food habits of Iowa foxes during a summer drought. Ecology, 18: 53-61.

12. Fairley J. S., 1970: The food, reproduction, form, growth and development of the fox (Vulpes vulpes) in north-est Ireland. Proc. R. Ir. Acad., 69: 103-137.

13. Hamilton W. J., 1935: Notes on food of red foxes in New York and New England. J. Mammal., 16: 16-21.

14. Karpuleon F., 1958: Food habits of Wisconsin foxes. J. Mammal., 39: 591-593.

15. Korschgen L. J., 1959: Food habits of the red fox in Missouri. J. Wildl. Manage., 23: 168-176.

16. Lever R., 1959: Diet of the fox since myxomatosis. J. Anim. Ecol., 28: 359-375.

17. Lockie J. D., 1959: Estimation of the food of foxes. J. Wildl. Manage, 23: $224-227$.

18. Lund H. M., 1959: The red fox in Norway. Meddr. St. Viltunders, 5: 1-57.

19. Lund H. M., 1962: The feeding habits of the red fox. Meddr. St. Viltunders, 12: $1-79$.

20. Mathiak H., 1983: A key to hairs of the mammals of Southern Michigan. J. Wildl. Manage., 2(4): 251-268.

21. Mayer W. V., 1952: The hair of California mammals with keys to the dorsal quard hairs of California mammals. The American Midland Naturalist, 48(2): $480-512$.

22. McIntosh D. L., 1963: Food of the red fox in the Canberra district. Wildl. Res., 8: $1-20$.

23. Middleton A. D., 1957: Game birds on the farm. Agriculture, Lond., 64: $345-347$.

24. Murie A., 1936: Following fox trails. Misc. Pub. Mus., Zool. Univ. Mich., 32 : $1-45$.

25. Papageorgiou N., Vlachos C. \& Neophytou C., 1981: Food habits of the red fox (Vulpes vulpes) in Macedonia. A Preliminary Report. Scientific Annals 
of the School of Agriculture \& Forestry, Univ. of Thessaloniki, Vol. 24(5): 181-193.

26. Richards D. F., 1977: Observations on the diet of the Red fox (Vulpes vulpes) in South Devon. J. Zool., Lond., 183: 495-504.

27. Richards S. H. \& Hine R. L., 1953: Wisconsin fox populations. Wis. Dep. Tech. Wildl. Bull., No. 6: 44-57.

28. Ryan G. E. \& Crift J. D., 1974: Observations on the food of the fox (Vulpes vulpes) in Kinchega National Park, Merindee, N.S.W. Aust. Wildl. Res., 1: $89-94$.

29. Schofield R. D., 1960: A thousand miles of fox trails in Michigan's ruffed grouse range. J. Wildl. Manage., 24: 432-434.

30. Scott T. G. \& Klimstra W. D., 1955: Red foxes and a declining prey population. South. III. Univ. Monogr. Ser. No. 1.

31. Southern H. N. \& Watson J. S., 1941: Summer food of the red fox in Great Britain. J. Anim. Ecol., 10: 1-11.

32. Stains H, J., 1958: Field guide to guard hairs of Middle-Western furbeares. J. Wildl. Manage., 22: 95-97.

33. Swanson G., 1940: Food habits of the sharp-tailed grouse by analysis of droppings. J. Wildl. Manage., 4: 432-436.

34. Vesey-Fitzgerald B., 1965: Town fox. Country fox. London.

35. Watson A., 1955: The winter food of six Highland foxes. Scott. Nat., 67: $123-124$.

Received 6 April 1987, Accepted 10 July 1987.

Nicolaos K. PAPAGEORGIOU, Athanasios I. SFOUGARIS,

Olga G. CHRISTOPOULOU, Christos G. VLACHOS i Jonh S. PETAMIDIS

\section{POKARM LISA W GRECJI}

\section{Streszczenie}

Zbadano zawartość 190 żołądków lisa Vulpes vulpes (Linnaeus, 1758) zebranych w latach $1982-85 \mathrm{w}$ Grecji. 165 żolądków zawierało mierzalne ilości pokarmu. Na pokarm lisów składało się ponad 70 gatunków ofiar, głównie kręgowców, lecz także bezkręgowce, zielone części roślin i owoce. Spośród kręgowców najczęstsze byly gryzonie, ssaki udomowione i drób, natomiast ssaki i ptaki lowne występowały rzadko (Tabele 2 i 3). Potwierdzono oportunistyczny charakter żerowania lisa, polegający na wykorzystywaniu przede wszystkim latwo dostępnych i obfitych rodzajów pokarmu. 